\title{
Possible Ameliorating Role of Ascorbic Acid on Intestinal Changes Induced by Acrylamide in Adult Female Albino Rats and Their Offsprings
}

\author{
Adel Mohamed Aboregela ${ }^{1,2}$, Amal Al-Shahat Ibrahim ${ }^{1}$, Nermin Raafat ${ }^{3}$ and \\ Norhan Sabbah \\ Original \\ Article \\ ${ }^{1}$ Department of Human Anatomy and Embryology, Faculty of Medicine, Zagazig University, \\ Egypt. \\ ${ }^{2}$ Department of Basic Medical Sciences, College of Medicine, University of Bisha, \\ Kingdom of Saudi Arabia.
}

${ }^{3}$ Department of Medical Biochemistry, Faculty of Medicine, Zagazig University, Egypt

\begin{abstract}
Background: Acrylamide (ACR) is a naturally occurring, widely used compound. Ingestion of large amounts of ACR underlies several health concerns and teratogenicity. Ascorbic acid (vitamin C) is a strong reducing agent greatly used to clean free radicals. This study investigated the morphometric, histological, immunohistochemical and biochemical disturbances induced by acrylamide $(10 \mathrm{mg} / \mathrm{kg} /$ day $)$ via gavage in the intestine of rat mothers and their offsprings. As well as, the protective role of ascorbic acid ( $100 \mathrm{mg} / \mathrm{kg} /$ day) via gavage.

Materials and Methods: Forty adult pregnant female rats were divided into four groups; control, ascorbic acid, acrylamide and acrylamide+ascorbic acid. 10 randomly chosen offsprings of each group after weaning were also used. Histomorphometric analysis of intestinal wall and biochemical analysis of intestinal enzymes, oxidant antioxidant markers and some genes expression were performed.

Results: In both dams and offsprings, ACR resulted in mucosal hyperplasia with evident inflammatory infiltration in the villi. In addition, goblet cells and KI67 + ve cell numbers decreased in the dams however increased in offsprings. ACR decreased citrate synthase, glutathione and catalase levels in dams and increased $\beta$-glucuronidase and malonaldehyde levels in dams. In offsprings, level of alkaline phosphatase was reduced and $\beta$-glucuronidase was elevated. Glutathione peroxidase and glutathione reductase mRNA expression was increased significantly with ACR ingestion. Ascorbic acid supplementation conserved the control status in the majority of conditions.

Conclusion: Acrylamide consumption during pregnancy and lactation is risky because of the induction of intestinal mucosal hyperplasia in rat offsprings. Ascorbic acid supplementation could reduce the harmful effects induced by ACR.
\end{abstract}

Received: 06 December 2019, Accepted: 19 February 2020

Key Words: intestine; lactation; morphometry; RT-qPCR; weaning.

Corresponding Author: Adel Mohamed Aboregela, MD, Department of Human Anatomy and Embryology, Faculty of Medicine, Zagazig University, Egypt, Basic Medical Sciences Department, College of Medicine, University of Bisha, Kingdom of Saudi Arabia, Tel.: +966 505163578, E-mail: amaboregela@zu.edu.eg, aaboregela@ub.edu.sa

ISSN: 1110-0559, Vol. 43, No.4

\section{INTRODUCTION}

Acrylamide (ACR) is an unsaturated amide compound containing a double bond that may react with nucleophiles ${ }^{[1]}$. Many occupational and environmental problems have been registered from the wide use of ACR which was primarily used as flocculants for clarifying drinking water ${ }^{[2]}$. Indeed, ACR is used mainly in the formation of polyacrylamides, which are used in a wide range in paints, plastics, varnishes, mortar and adhesives. Also, it is applied in toiletries and cosmetics ${ }^{[3]}$. Naturally, ACR is formed through the interaction of amino acids with reducing sugars. This occurs during frying, grilling, baking or roasting carbohydrate rich food as bread, crisps of potato, chips crackers and French fries at temperatures above $120^{\circ} \mathrm{c}$. This increased the concern about the risks of cancer related to the dietary intake of fried or backed food rich in carbohydrates ${ }^{[, 5]}$.

It was evident that large doses of ACR can cause injury to the male reproductive organs. Adding to this, ACR inhalation directly or skin absorption irritates the exposed tissue and can lead to nausea, sweating, speech disorders, paresthesia, numbness, myalgia, urinary incontinence and paraparesis ${ }^{[6]}$. As well as, it has a carcinogenic effect in rodents ${ }^{[7,8]}$. Many 
studies showed that ACR is absorbed rapidly and effectively by means of the gastrointestinal tract ${ }^{[9,10]}$. In humans and animals, it can pass through the placental barrier. So that maternal exposure is an evident measure for fetal exposure to Acrylamide ${ }^{[11]}$.

Ascorbic acid (vitamin C) is found in animals and plants as a naturally occurring organic compound. It works as a redox buffer that can reduce and neutralize reactive oxygen species $^{[12]}$. As a water-soluble molecule, vitamin $\mathrm{C}$ can function inside and outside the cells ${ }^{[13]}$. Also, it is a strong reducing agent that can scavenge free radicals in different biological systems ${ }^{[14]}$. Therefore, this study was designed to clarify the effect of acrylamide and the expected ameliorative effect of vitamin $\mathrm{C}$ on adult female rat intestine and their offsprings.

\section{MATERIALS AND METHODS}

\subsection{Experimental animals}

Forty adult female and twenty adult male Wistar Albino rats (twenty weeks old; each weighing between 180 and $210 \mathrm{~g}$ ) were used in this study. All animals were purchased from Zagazig Scientific and Medical Research Center (ZSMRC) animal house. All the rats were housed in a 12 hour day/12 hour night circle (lights on at 7 a.m.) at constant room temperature $\left(21-22^{\circ} \mathrm{C}\right)$ in groups of five in standard plastic cages. Rats were allowed seven days for accommodation before mating and were given free access to food and water. Adult females were housed with adult males at a ratio of 2:1 respectively per cage for mating. Vaginal smear was checked in the next morning to look for sperms. The day in which sperms were identified in the vaginal smear was considered as day ' 0 ' of gestation.

All the experiments were carried out according to EU Directive 2010/63/EU for animal experiments ${ }^{[15]}$. This study was assent by the Institutional Animal Care and Use Committee in Zagazig University (ZU-IACUC/3/F/84/2018).

\subsection{Experimental chemicals}

ACR (99\% pure) was purchased from Sigma chemical Company (St Louis, MO, USA). Vitamin C (pure ascorbic acid powder) was obtained from El Gomhouria Company for Chemical and Medical Trading, Zagazig, Egypt. Both powders were dissolved in distilled water to be administered orally via gavage to non-anesthetized pregnant rats. All solutions were freshly prepared daily.

\subsection{Dosing and experimental methods}

Pregnant rats were grouped into four experimental groups (10 rats / each group). Group I (negative control group) in which the rats received distilled water per oral only. Group II (positive control group), the animals were administered vitamin $\mathrm{C}$ via gavage at a dose of $100 \mathrm{mg} /$ $\mathrm{kg} /$ day $^{[16]}$. Group III (ACR treated group) in which the rats were given ACR at a dose of $10 \mathrm{mg} / \mathrm{kg} /$ day orally ${ }^{[17]}$. Group IV (ACR+Vit C group) the animals received $10 \mathrm{mg} / \mathrm{kg} /$ day
ACR supplemented by $100 \mathrm{mg} / \mathrm{kg} /$ day vitamin $\mathrm{C}$ by mouth. Animal dosing started at the tenth day (D10) of gestation and maintained daily up to the twenty first day (D21) after birth (until the pups were weaned).

Then at the end of the experiment, all the ten dams and ten randomly chosen offsprings from each group were anesthetized using intraperitoneal injection of thiopental $\mathrm{Na} 30 \mathrm{mg} \mathrm{kg}$. Laparotomy was done and two, ten $\mathrm{mm}$ long, pieces of the small intestine, one from the duodenum (ten $\mathrm{mm}$ after the pylorus) and the second one from the middle of the total intestinal length (representing jejunum), were taken from each animal and immersed in 10\% neutral buffered formalin for histological analysis. Another, ten mm long segment was taken from the rest of the small intestine from each animal and kept in PBS for biochemical analysis.

\subsection{Microscopic analysis}

\subsubsection{Hematoxylin and Eosin staining ( $H \& E)$}

Small intestine samples were processed and inserted in paraffin. Serial sections of 4-5 micrometer thickness were mounted and stained with hematoxylin \& eosin $(\mathrm{H} \& \mathrm{E})^{[18]}$.

\subsubsection{Immunohistochemistry}

Immunohistochemistry staining was applied to 4-5 micrometer thickness sections ${ }^{[19]}$. In brief, the sections were deparaffinized, rehydrated and rinsed in tap water. The specimens were treated with 3\% hydrogen peroxide for $10 \mathrm{~min}$ then immersed in antigen retrieval solution. $10 \%$ normal goat serum in phosphate buffer solution (PBS) was used to block nonspecific protein binding. The slides were incubated with anti-KI67 (Rabbit Polyclonal antibody, Cat: RB-9043-R7, Lab-Vision, USA) at dilution of 1:300. Biotinylated secondary antibody was added to the sections for one hour at the room temperature after PBS wash. Streptavidin peroxidase was added for $10 \mathrm{~min}$ and then washed in PBS. Counterstaining by Mayer's hematoxylin was performed. The primary antibody stage was excluded in negative controls. The cellular stainings was assessed in duplicates.

\subsubsection{Image analysis and morphometry}

All sections were examined and photographed using Leica DM500, (German) photomicroscope. Images were analyzed, and different parameters were measured using ImageJ (FIJI) software. In Hematoxylin and Eosin stained sections, mucosal thickness, submucosal thickness, myenteron thickness, villus length (from the tip of the villus to the villus-crypt junction), villus width (estimated in the middle of villus height), crypt width (or distance between villi) and villus epithelium thickness were measured. In addition, enterocytes and goblet cells per $100 \mu \mathrm{m}$ of villus epithelium were counted. Moreover, the small intestine absorptive surface was calculated ${ }^{[20]}$. In KI67 stained sections, the number of proliferating cells per $1 \mathrm{~mm} 2$ and the optical density of the reaction were measured. 


\subsection{Biochemical analysis}

\subsubsection{Tissues elaboration and protein content measurement}

Intestinal samples were rinsed with PBS to remove any contents and then the tissues were homogenized by the use of tissue grinder. To elevate homogeneity of the tissue by rupturing membranes, the samples were frozen quickly in liquid nitrogen, thawed in ice and assayed quickly ${ }^{[21]}$. Protein content was estimated using the phenol reagent according to Lowry et al. ${ }^{[22]}$.

\subsubsection{Intestinal enzymes assessment}

All the assays were done at optimal cofactor and substrate concentrations. End-point spectrophotometric assay was formed for $\beta$-glucuronidase. Kinetic spectrophotometric assays were done for alkaline phosphatase, citrate synthase, and lactate dehydrogenase. Alkaline phosphatase was estimated at $405 \mathrm{~nm}$ using $15 \mathrm{mM}$ p-nitrophenyl phosphate and $0.1 \mathrm{M}$ diethanolamine adjusted to $\mathrm{pH} 9.8$ with $1.0 \mathrm{~N}$ $\mathrm{HCL}^{[23]}$.

In the presence of the enzyme and oxaloacetate at $\mathrm{pH}$ 8.0, Citrate synthase was determined by quantitating the free coenzyme A released from acetyl- $(\mathrm{CoA})^{[24]}$. Lactate dehydrogenase was assayed by following the rate of NADH (Nicotinamide adenine dinucleotide reduced) oxidation. After the final addition of $0.25 \mathrm{mM}$ pyruvate. NADH oxidation was read at $340 \mathrm{~nm}^{[25]}$.

$\beta$-glucuronidase was measured by modifying Lucier and McDaniel $^{[26]}$ method with $\mathrm{p}$ nitrophenyl $+\mathrm{D}$-glucuronide as the substrate in a final volume of $0.4 \mathrm{ml}$. Neither in vitro pre-incubation of tissue slices from the small intestine with 3 to $300 \mathrm{mM}$ acrylamide at $37^{\circ} \mathrm{C}$ for 1 hour nor the addition of $30 \mathrm{mM}$ acrylamide to the assay mixtures had no effect on the activities of enzymes ${ }^{[26]}$.

\subsubsection{Intestinal oxidant-antioxidant markers assessment}

Malondialdehyde (MDA) was assessed using spectrophotometer according to Ohkawa et. al. ${ }^{[27]}$. Reduced glutathione (GSH) was assessed using the method described by Beutler ${ }^{[28]}$. Superoxide dismutase (SOD) activity was assessed using the method reported by Sun et. al. ${ }^{[29]}$. Catalase (CAT) activity was assessed using the method reported by Wahlefeld ${ }^{[25]}$. The observed optical density (OD) was recorded for one minute on the spectrophotometer to measure the activity of the enzyme.

\subsubsection{Quantitative real time (PCR) RT-qPCR for glutathione peroxidase, glutathione reductase, glutathione S-transferase genes expression}

RNA was extracted from the intestinal tissue using RNA Mini kit according to the manufacturer's protocol (Qiagen RNeasy, Germany). The isolated RNA has an A 260/280 ratio of 1.9-2.0. cDNA was synthesized from RNA by reversal transcription with a Super-Script ${ }^{\mathrm{TM}_{\mathrm{C}} \mathrm{CDNA} \text { synthesis }}$ kit (Invitrogen, CA, USA). Expression levels of mRNA were determined by Stratagene, MX3000P quantitative (PCR) System (Agilent Technologies) and analyzed using MxPro QPCR Software (Agilent Technologies). Primers used for glutathione peroxidase, glutathione reductase, glutathione S-transferase and GAPDH as housekeeping gene according to Al-Rejaie et. al. ${ }^{[30]}$ (Table 1).

Table 1: Primers of GAPDH, glutathione peroxidase, glutathione reductase and glutathione S-transferase genes

\begin{tabular}{|c|c|}
\hline Target & Sequence \\
\hline GAPDH & $\begin{array}{l}\text { Forward: 5'- TGGCCTCCAAGGAGTAAGAAAC -3' } \\
\text { Reverse: 5'- GGCCTCTCTCTTGCTCTCAGTATC -3' }\end{array}$ \\
\hline $\begin{array}{l}\text { Glutathione } \\
\text { peroxidase }\end{array}$ & $\begin{array}{l}\text { Forward: 5'- GGTGTTCCAGTGCGCAGAT -3' } \\
\text { Reverse: 5'- AGGGCTTCTATATCGGGTTCGA -3' }\end{array}$ \\
\hline $\begin{array}{l}\text { Glutathione } \\
\text { reductase }\end{array}$ & $\begin{array}{l}\text { Forward: 5'- TGAGCCGCCTGAACAACA-3' } \\
\text { Revere: 5'-TGACACAATACACGGGATCTG -3' }\end{array}$ \\
\hline $\begin{array}{l}\text { Glutathione } \\
\text { S-transferase }\end{array}$ & $\begin{array}{l}\text { Forward: 5'-AATATGTCCCCCAGACCAAAGA-3' } \\
\text { Reverse: 5'-GGCAGGCAAGTACCGGTTT-3' }\end{array}$ \\
\hline
\end{tabular}

The PCR was performed in $25 \mu$ l containing $12.5 \mu 12 \mathrm{x}$ QuantiFast (PCR) Master Mix, $1 \mu \mathrm{M}$ of each primer (all primers were synthesized by Jena bioscience Germany) and $5 \mu 1 \mathrm{cDNA}$ with the following conditions: $95^{\circ} \mathrm{C}$ for 5 minutes, then 40 cycles at $94^{\circ} \mathrm{C}$ for $30 \mathrm{sec}$, and combined annealing and extension $\left(60^{\circ} \mathrm{C}\right)$ for $60 \mathrm{sec}$. All kits were supplied by QIAGEN, Valencia, CA, USA.

The samples were repeated in duplicates to make sure of the accuracy and reproducibility of the obtained results. At the end, a melting curve analysis was performed from $60^{\circ} \mathrm{C}$ to $95{ }^{\circ} \mathrm{C}$. The real time (PCR) records a value $(\mathrm{Ct})$ with the same threshold cycle of specific target gene amplification at which the PCR products are detected by fluorescence. After amplification, analysis of the melting curve was performed to refine the correct product according to the melting temperature $(\mathrm{Tm})$.

\subsection{Statistical interpretation}

GraphPad Prism 5 software (GraphPad Software, San Diego, CA, USA) was used to analyze all the data. Summarization of the data was performed as a mean and standard deviation. Analysis of variance (ANOVA) was used to test the differences between the mean values of experimental groups with a post hoc Tukey's multiple comparison test. The difference was considered statistically significant when $p$-value $<0.05$.

\section{RESULTS}

\subsection{Histopathology and morphometry}

In dams, the duodenal mucosal thickness, villi width, crypt width and villus epithelial thickness increased with ACR treatment. However, the submucosa, myenteron, goblet cell numbers and the absorptive surface showed a significant decrease. Vit $\mathrm{C}$ supplementation markedly improved the conditions regarding mucosal thickness, villus epithelial thickness and the number of goblet cells (Table $2 \mathrm{~A}$ ).

In addition, the epithelial covering of the villi turned very high columnar with rarefaction of the cytoplasmic density 
after ACR ingestion. Furthermore, the different cores of the villi demonstrated marked infiltration by inflammatory cells with darkly stained nuclei and some vacuolation (Figure 1 $\mathrm{A}$ and $\mathrm{B}$ ). Adding vitamin $\mathrm{C}$ preserved the columnar state and the cytoplasmic staining density of the villus epithelium. However, did not protect the core from inflammatory infiltration (Figure $1 \mathrm{C}$ ).

The state in the jejunum was different, there was augmentation in the mucosal and submucosal thicknesses, villi length and width and absorptive surface after ACR therapy. Yet, goblet cells number and villus epithelium thickness decreased although, enterocytes number raised. The changes in the submucosa, villi length and epithelium thickness, goblet cells and absorptive surface were enhanced in the ACR + vit $\mathrm{C}$ group (Table $2 \mathrm{~A}$ ).

ACR ingestion changed the jejunal villus epithelium into cuboidal cells, instead of columnar, with rarefaction of the cytoplasmic density in some cells and mild inflammatory cells invasion of the core (Figure $1 \mathrm{D}$ and $\mathrm{E}$ ). The columnar state of the epithelium was conserved by vit $\mathrm{C}$ co-treatment however, the core infiltration was not prevented (Figure $1 \mathrm{~F}$ ).

The offsprings demonstrated increase in all the duodenal parameters except villi width and the absorptive surface. Furthermore, vitamin $\mathrm{C}$ ameliorated all the duodenal altered parameters except villi length and crypt width (Table $2 \mathrm{~A}$ ). The villi epithelium became more columnar with vacuolation and rarefaction of the cytoplasm. Adding to that, there were several areas with multilayered epithelium where the cells were cuboidal, aggregated and hyperplastic. Moreover, the villus core showed mild infiltration (Figure $2 \mathrm{~A}$ and $\mathrm{B}$ ). The single layered columnar state of the epithelium was kept with vitamin $\mathrm{C}$ addendum, but the inflammatory infiltration of the core persisted (Figure 2 C).

Regarding the jejunum of the offsprings, the thickness of the mucosa and submucosa, villi length and width, crypt width and villus epithelial thickness were decreased markedly but the enterocytes and goblet cell numbers raised after ACR treatment. Adding vitamin $\mathrm{C}$ recovered all the previous changes in the jejunum except for villus epithelium thickness (Table $2 \mathrm{~A}$ ).

Mitotic figures were clearly apparent in the villus surface epithelium of the offsprings' jejunum in all groups. However, the cells were less columnar with multiple hyperplastic foci where the cells were multilayered after ACR therapy (Figure $2 \mathrm{D}$ and E). Villus core showed mild inflammatory infiltration. Vitamin $\mathrm{C}$ boosting conserved neither the columnar state of villus surface epithelium nor the core infiltration (Figure $2 \mathrm{~F}$ ). All the measured parameters, either in the dams or their offsprings, had no significant difference between the control and vitamin $\mathrm{C}$ supplemented groups.

\subsection{Immunohistochemistry and morphometry}

The duodenum of the dams received ACR demonstrated reduction in the number and optical density of the proliferating cells (KI67 positive cells). Indeed, the optical density but not the number of KI67 + ve cells recovered after $\mathrm{ACR}+$ vit $\mathrm{C}$ co-treatment (Table $2 \mathrm{~B}$ and Figure $3 \mathrm{~A}, \mathrm{~B}$ and C). However, only the optical density of KI67 decreased in the jejunum of the dams after ACR treatment and showed no progress after vitamin $\mathrm{C}$ co-treatment (Table $2 \mathrm{~B}$ and Figures $3 \mathrm{D}, \mathrm{E}$ and F).

The proliferating cells (KI67 positive cells) number and the optical density raised markedly in the duodenum of the offsprings. Vit $\mathrm{C}$ supplementation ameliorated the conditions of KI67 positive cell number however, no change appeared in the optical density (Table $2 \mathrm{~B}$ and Figures $3 \mathrm{G}, \mathrm{H}$ and I). Concerning, the jejunum of the offsprings, there was an increase in the number of KI67 positive cells and the optical density with no refinement after vitamin $\mathrm{C}$ administration (Table $2 \mathrm{~B}$ and Figures $3 \mathrm{~J}, \mathrm{~K}$ and L).

\subsection{Biochemical analysis}

Multiple intestinal enzymes (lactate dehydrogenase, alkaline phosphatase, citrate synthase and $\beta$-glucuronidase) were measured to assess the probability ACR toxicities of the dams and offsprings. In the dams, citrate synthase decreased but, $\beta$-glucuronidase increased after ACR treatment. Vitamin $C$ augmentation preserved only the level of $\beta$-glucuronidase (Figure $4 \mathrm{~A}$ ). Concerning the offsprings, alkaline phosphatase was reduced and $\beta$-glucuronidase was raised by ACR treatment. ACR + Vit $\mathrm{C}$ supplementation maintained the level of $\beta$-glucuronidase only within the control range (Figure $4 \mathrm{~B}$ ).

In addition, different intestinal oxidant-antioxidant markers (malonaldehyde, reduced glutathione, superoxide dismutase and catalase) were assessed in dams and offsprings. There was elevation in the level of malonaldehyde while lowering in reduced glutathione and catalase levels in dams. All the levels were safeguarded by vitamin $\mathrm{C}$ addition (Figure $4 \mathrm{C}$ ). But, malonaldehyde and catalase levels in offsprings were altered by ACR treatment showing increase and decrease, respectively. This was corrected by vitamin $\mathrm{C}$ integration (Figure 4 D).

Quantitative real time PCR (qRT-PCR) showed exaggeration of both glutathione peroxidase and glutathione reductase mRNA expression after ACR + vit C supplementation in contrast to the control group while their expression decreased by ACR ingestion for both dams and offsprings. In contrast, glutathione S-transferase mRNA expression increased significantly with ACR ingestion but decreased slightly after $\mathrm{ACR}+$ vit $\mathrm{C}$ co-treatment (Figures $4 \mathrm{E}$ and $\mathrm{F}$ ). 

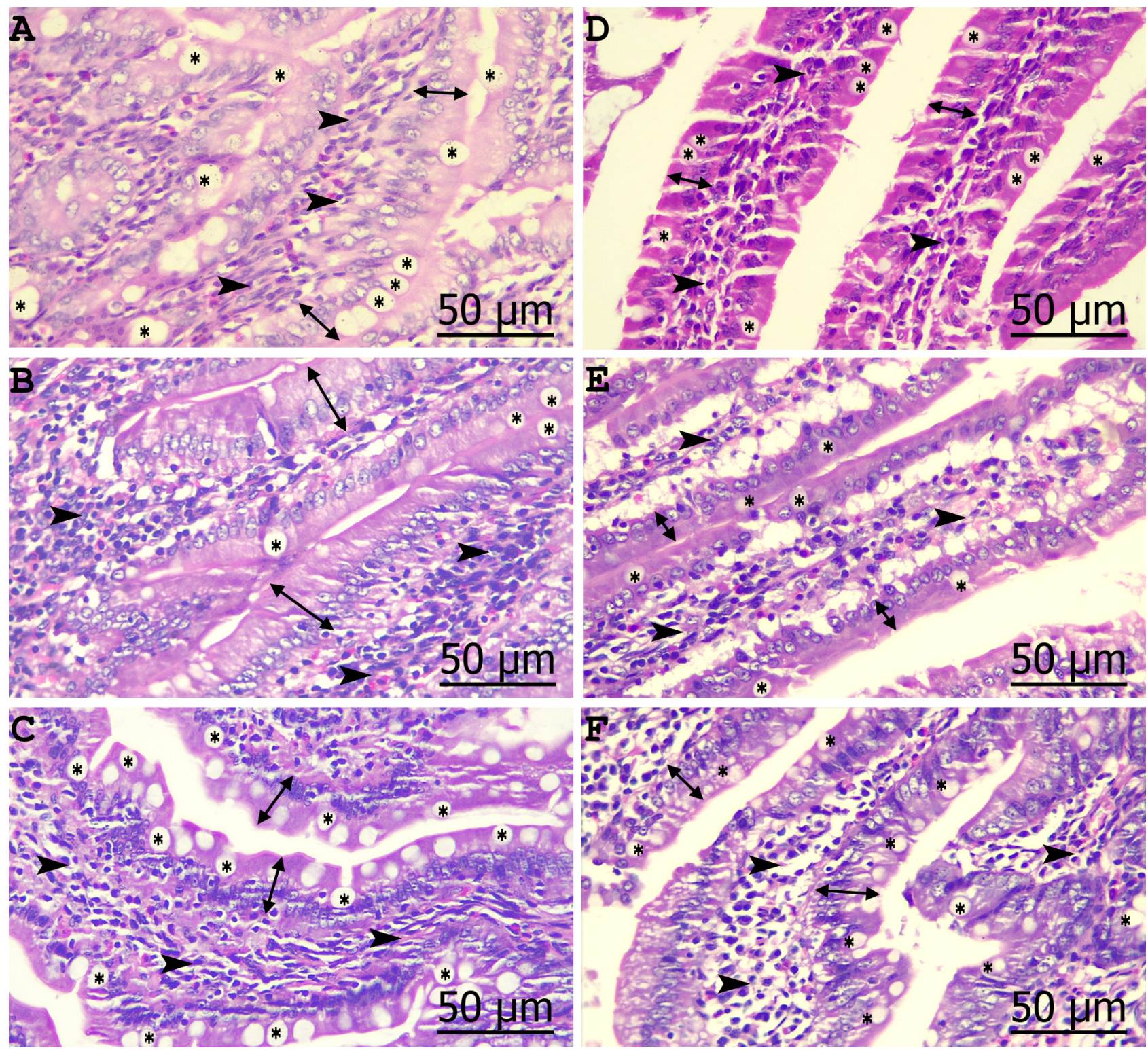

Fig. 1: Representative photomicrographs of hematoxylin and eosin-stained (H\&E) sections from the small intestine of the dams. The duodenum: (A, B and C). The jejunum: (D, E and F). The groups are arranged as control, ACR and ACR+ vitamin C respectively. Goblet cells (*), villus mucosa ( $\uparrow)$ and core lamina propria (Arrow heads) $(\mathrm{H} \& \mathrm{E}, \mathrm{Bar}=50 \mu \mathrm{m})$ 

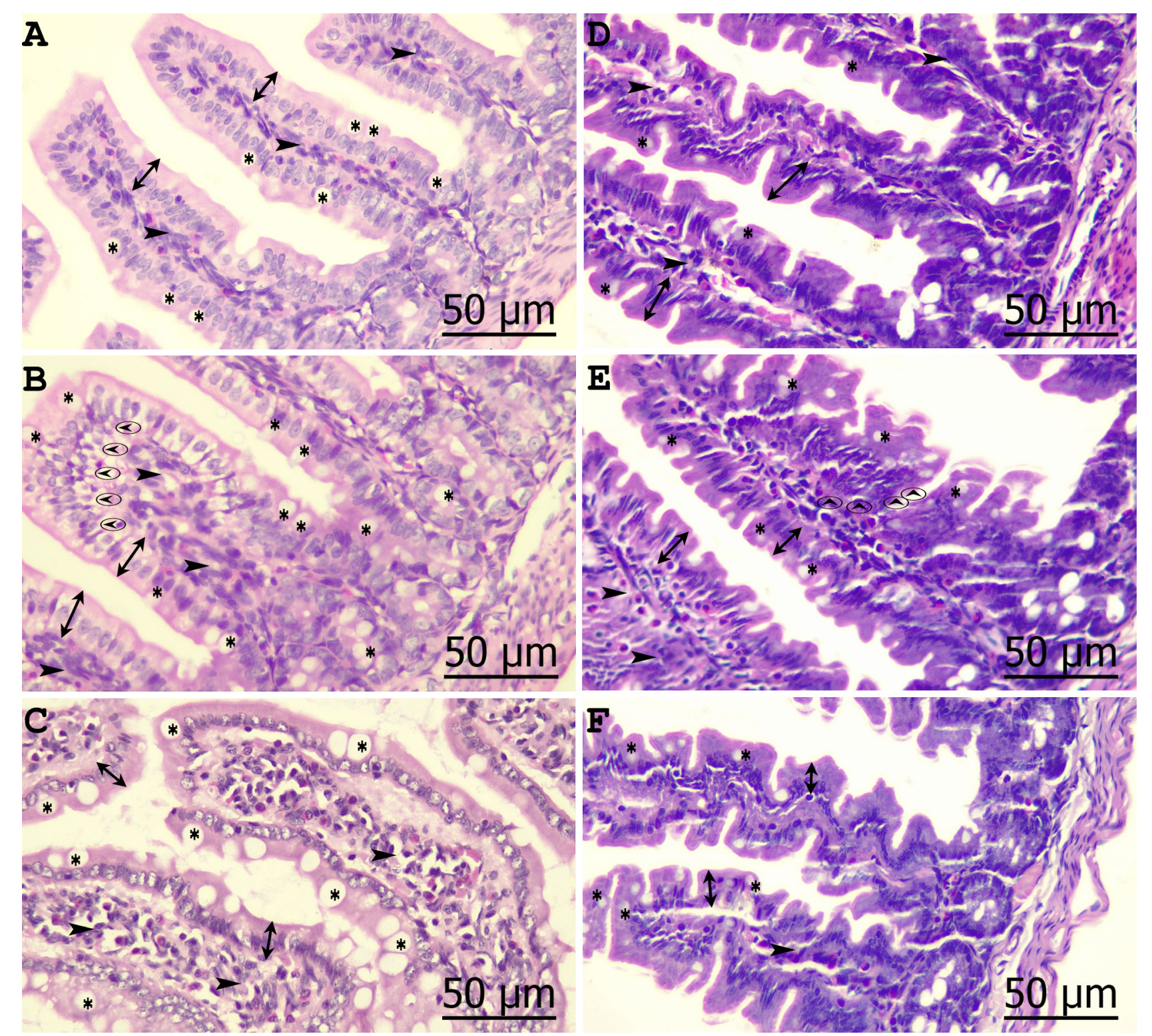

Fig. 2: Representative photomicrographs of hematoxylin and eosin-stained (H\&E) sections from the small intestine of the offsprings. The duodenum: (A, B and C). The jejunum: (D, E and F). The groups are arranged as control, ACR and ACR+ vitamin C respectively. Goblet cells $(*)$, villus mucosa $(\uparrow)$, multilayered epithelium (Arrow head in circle) and core lamina propria (Arrow heads) $(\mathrm{H} \& \mathrm{E}, \mathrm{Bar}=50 \mu \mathrm{m})$ 


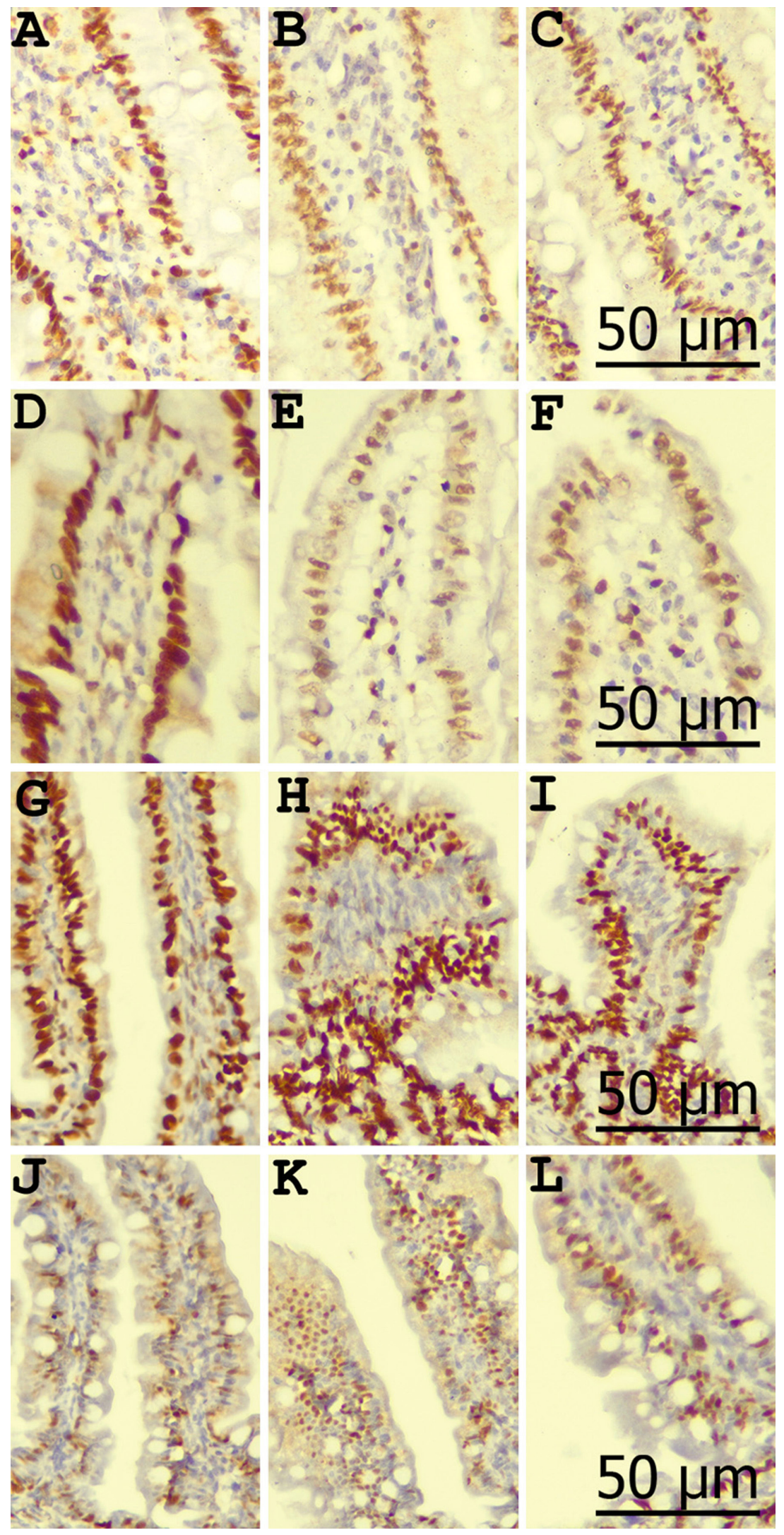

Fig. 3: Representative photomicrographs of KI67 immunostaining of the intestine. The dams' duodenum (A, B and C), dams' jejunum (D, E and F), offsprings' duodenum $(\mathrm{G}, \mathrm{H}$ and $\mathrm{I})$ and offsprings' jejunum $(\mathrm{J}, \mathrm{K}$ and $\mathrm{L})$. The groups are arranged as control, ACR and ACR+ vitamin $\mathrm{C}$ respectively $(\mathrm{KI} 67, \mathrm{Bar}=50 \mu \mathrm{m})$ 


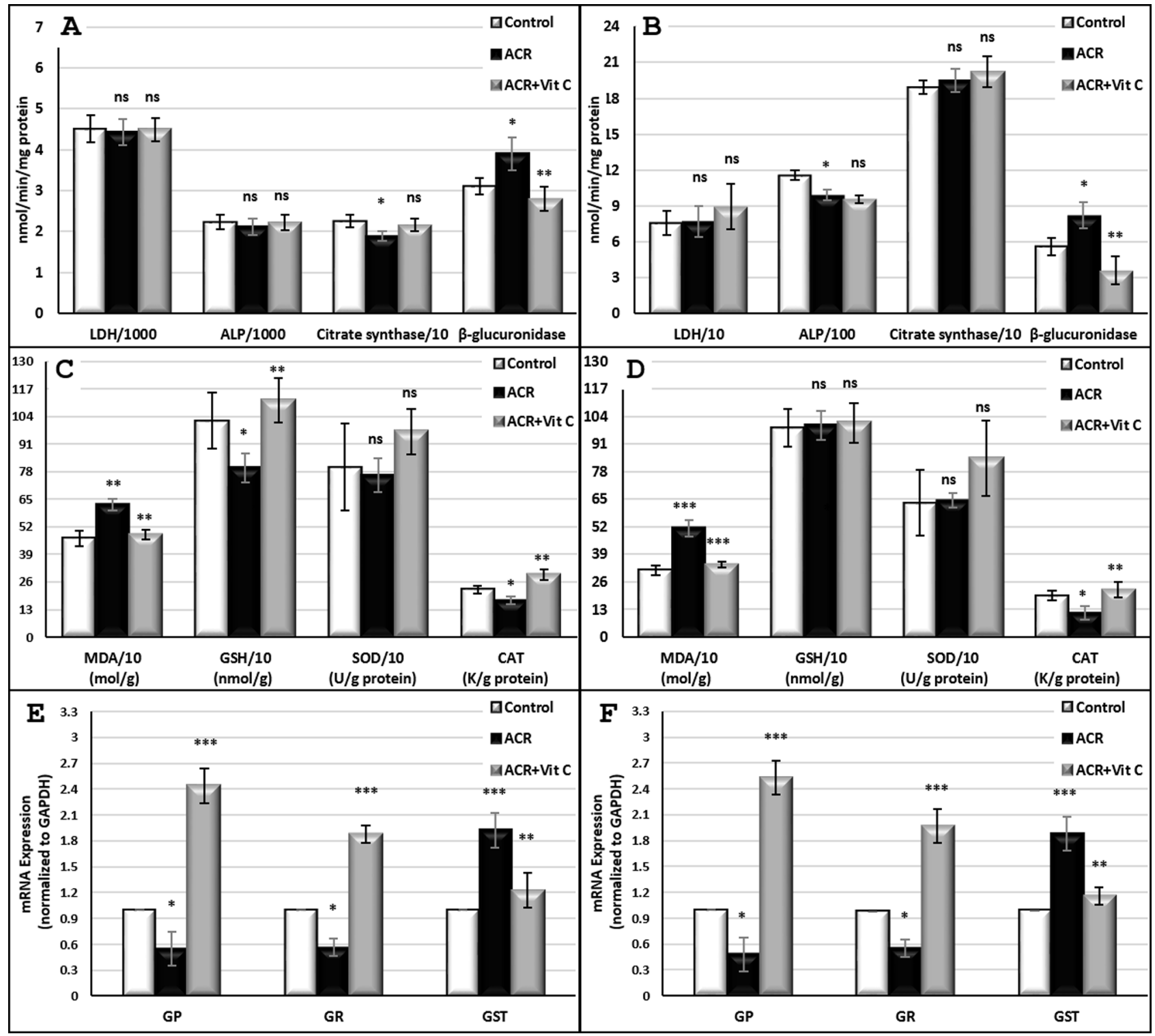

Fig. 4: Intestinal enzymes assessment in dams and offsprings respectively (A and B). Different intestinal oxidant-antioxidant markers estimation in dams and offsprings respectively (C and D). Quantitative real time PCR (qRT-PCR) for mRNA expression in dams and offsprings respectively (E and F). Values are presented as means \pm SD. *: $P<0.05$, **: $P<0.01$, ***: $P<0.001$ and ns: no significance 


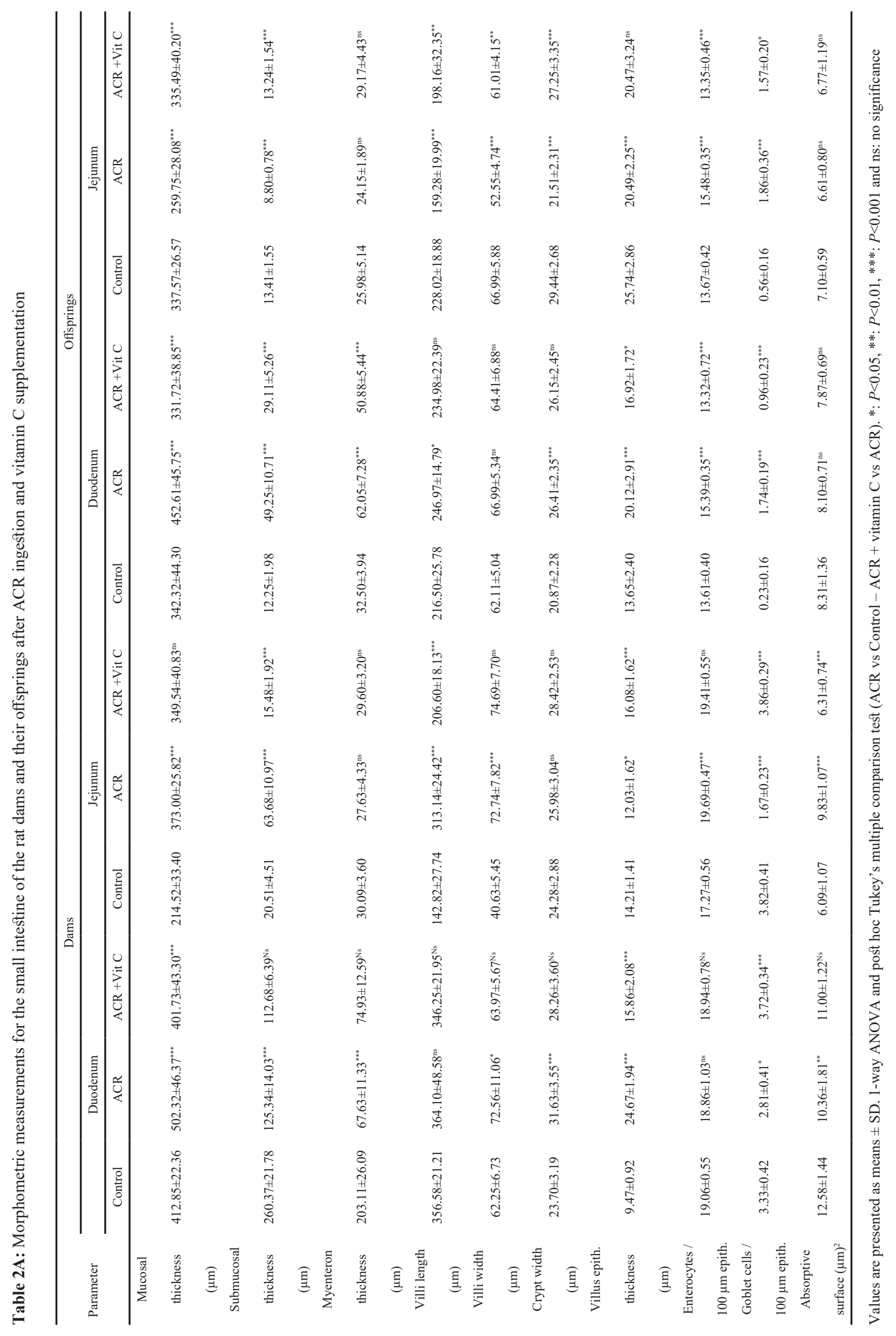




\section{DISCUSSION}

Acrylamide (ACR) is a water soluble and easily distributed compound ${ }^{[31]}$. It is formed in carbohydrate foods that prepared at high temperatures ${ }^{[32]}$. ACR can reach the offsprings transplacentally ${ }^{[33]}$. Also, it can pass through mother's milk during lactation ${ }^{[34]}$. As the gastrointestinal tract (GIT) is a main target for direct toxicity of ACR, and the ACR is rapidly absorbed in the intestine ${ }^{[35]}$. This study aimed to identify the changes occurring in the small intestine of pregnant female rats exposed to ACR $(10 \mathrm{mg} / \mathrm{kg} / \mathrm{day})$ and their offsprings and the possible protective role of vitamin $\mathrm{C}$ (100 mg/kg/day).

It was clear that, acrylamide exposure induces histological changes in both duodenal and jejunal mucosae of dams. There was hypertrophy in epithelium of the duodenal villi where the cells were columnar and turned very high columnar. However, the mucosal cells atrophied and turned cuboidal, from columnar, in the jejunum with rarefaction of the cytoplasmic density.

Moreover, the villi were infiltrated by inflammatory cells with dark stained nuclei and vacuolation. This was together with variations in different intestinal enzymes where, citrate synthase decreased but, $\beta$-glucuronidase increased after ACR therapy. This is in accordance with Altinoz and Turkoz ${ }^{[36]}$ who reported that oral administration of acrylamide to rats in a dose of $25 \mathrm{mg} / \mathrm{kg} /$ day for 21 days caused damage in villi with rubbing off epithelial lining and decreased cell density in the lamina propria. Also, Gedik et al ${ }^{[37]}$ observed shortened villi with damaged epithelium and degenerated lamina propria with moderate cellular infiltration.

It was stated that, the type of intrauterine growth can affect the post-natal functions of intestines ${ }^{[38]}$. Also, acrylamide and its metabolite glycidamide can cause multiple defects in offsprings' organogenesis including digestive tract ${ }^{[39]}$.

Regarding the small intestinal mucosa in the offsprings of the current study, the epithelium of the villi became more columnar in duodenum while less columnar in jejunum with several areas of hyperplasia. In addition, cell proliferation increased greatly in both duodenum and jejunum, this was detected by KI 67 expression. As well as, there was reduction in alkaline phosphatase however, rising in $\beta$-glucuronidase induced by ACR treatment. This is in consistence with Ølstørn et $a l^{[40]}$ who demonstrated haggard but significant carcinogenic activity in small intestine of $\mathrm{Min} /+$ mice and their wild type litter mates after perinatal exposure to acrylamide and its metabolite glycidamide.

Furthermore, the study conducted on Syrian hamster embryo cell culture elucidated, morphological transformation in embryonic cells after injection with $0.5 \mathrm{M}$ of acrylamide for 7 days $^{[41]}$. However, the study carried out by Maronpot et $a l^{[42]}$ revealed that in utero exposure to acrylamide elevate the incidence of thyroid follicular neoplasms in males and females with no signs of carcinogenicity in small intestine of Wistar Han rats.
ACR generates free radicals disrupting the antioxidative state leading to oxidative stress and tumorigenesis ${ }^{[43]}$. Oxidative stress is considered indirect genotoxic factor as it is included in tumor promotion, mutation and chromosomal aberration ${ }^{[44]}$. This was confirmed by the increase in the level of malonaldehyde while lowering in reduced glutathione and catalase levels in this study. The results of the present study showed decrease in glutathione peroxidase and glutathione reductase mRNA expression in intestinal tissues of both dams and offsprings after ACR ingestion. However, glutathione S-transferase (GST) expressions are selectively up-regulated in intestinal tissues of ACR dosed rats. This increase in GST expression may be due to the modulations of GST levels on c-jun N-terminal Kinase by synthesis of GST-JNK complex integrity in sequence to decrease its activation. This was consistent with Turella et $a l^{[45]}$ and Burg et a ${ }^{[46]}$.

Vitamin $\mathrm{C}$ is considered the most important watersoluble antioxidant in mammalian cells ${ }^{[14]}$. In the present investigation, it was confirmed that addition of vitamin $\mathrm{C}$ corrects most of the disturbances induced by acrylamide in both the dams and the offsprings' intestinal tissue. This ameliorating effect of vitamin $\mathrm{C}$ would be due to oxidative damage block in these cell populations ${ }^{[47]}$.

Simán and Eriksson ${ }^{[48]}$ treated pregnant streptozotocin induced diabetic rats with vitamin $\mathrm{C}$ and mentioned that it had the potential to prevent congenital malformations in the offsprings. It was suggested by Granath et $a^{l^{[2]}}$ that antioxidative treatment with vitamin $\mathrm{C}$ diminishes oxygen radical related tissue damage which decreases fetal malformations.

\section{CONCLUSION}

Acrylamide consumption in the periods of pregnancy and lactation in rats is highly risky because of the induction of mucosal hyperplasia in the offsprings' intestine. This is a promising future research point that could give an idea about the suitable nutritional measures to decrease the risk of exposure to acrylamide.

\section{ACKNOWLEDGMENTS}

All the authors feel thankful to the staff of Zagazig Scientific and Medical Research Center (ZSMRC) for hosting the experiments in their laboratories.

\section{AUTHOR CONTRIBUTION}

The four authors shared in designing the experiments. A. A. Ibrahim and N. Sabbah performed data acquisition. Data analysis and interpretation was carried out by A. M. Aboregela and N. Raafat., A. A. Ibrahim and A. M. Aboregela drafted the manuscript. N. Raafat and N. Sabbah acuretly revised the manuscript and the four authors approved the article.

\section{CONFLICTS OF INTEREST}

There are no conflicts of interest 


\section{REFERENCES}

1. Blasiak, J., Gloc, E., Wozniak, K., and Czechowska, A. (2004). Genotoxicity of acrylamide in human lymphocytes. Chemico-biological interactions, 149 (2-3), 137-149.

2. Granath, F., Ehrenberg, L., Paulsson, B., and Törnqvist, M. (2001). Cancer risk from exposure to occupational acrylamide. Occupational and Environmental Medicine, 58 (9), 608-609.

3. Pingot, D., Pyrzanowski, K., Michałowicz, J., and Bukowska, B. (2013). Toxicity of acrylamide and its metabolite-glicydamide. Medycyna pracy, 64 (2), 259-271.

4. Tareke, E., Rydberg, P., Karlsson, P., Eriksson, S., and Törnqvist, M. (2002). Analysis of acrylamide, a carcinogen formed in heated foodstuffs. Journal of agricultural and food chemistry, 50 (17), 4998-5006.

5. Zhang, Y., Zhang, G., and Zhang, Y. (2005). Occurrence and analytical methods of acrylamide in heat-treated foods: Review and recent developments. Journal of Chromatography A, 1075 (1-2), 1-21.

6. Alberts, B., Johnson, A., Lewis, J., Walter, P., Raff, M. and Roberts, K., (2002). Molecular Biology of the Cell. 4th Edition: (New York: Garland Science). 91,401

7. LoPachin, R. M. (2005). Acrylamide neurotoxicity: neurological, morphological and molecular endpoints in animal models. In Chemistry and safety of acrylamide in food Springer, Boston, MA, 21-37.

8. Rice, J. M. (2005). The carcinogenicity of acrylamide. Mutation Research/Genetic Toxicology and Environmental Mutagenesis, 580 (1-2), 3-20.

9. Ikeda, G. J., Miller, E., Sapienza, P. P., Michel, T. C. and Inskeep, P. B. (1987). Comparative tissue distribution and excretion of [1-14C] acrylamide in beagle dogs and miniature pigs. Food and Chemical Toxicology, 25 (11), 871-875.

10. Shipp, A., Lawrence, G., Gentry, R., McDonald, T., Bartow, H., Bounds, J., Macdonald, N., Clewell, H., Allen, B. and Van Landingham, C. (2006). Acrylamide: review of toxicity data and doseresponse analyses for cancer and noncancer effects. Critical reviews in toxicology, 36 (6-7), 481-608.

11. Schettgen, T., Rossbach, B., Kütting, B., Letzel, S., Drexler, H. and Angerer, J. (2004). Determination of haemoglobin adducts of acrylamide and glycidamide in smoking and non-smoking persons of the general population. International journal of hygiene and environmental health, 207 (6), 531-539.

12. Pehlivan, F. E. (2017). Vitamin C: An antioxidant agent. Vitamin C, 2, 23-35.
13. Bindhumol, V., Chitra, K. C. and Mathur, P. P. (2003). Bisphenol A induces reactive oxygen species generation in the liver of male rats. Toxicology, 188 (2-3), 117-124.

14. Duarte, T. L. and Lunec, J. (2005). When is an antioxidant not an antioxidant? A review of novel actions and reactions of vitamin C. Free radical research, 39 (7), 671-686.

15. European Commission. (2010). Directive 2010/63/ EU of the European Parliament and of the Council of 22 September 2010 on the protection of animals used for scientific purposes. Off. J. Eur. Union, 53 (L 276), 33-79.

16. Uboh, F. E., Ebong, P. E., Akpan, H. D. and Usoh, I. F. (2012). Hepatoprotective effect of vitamins $\mathrm{C}$ and $\mathrm{E}$ against gasoline vapor-induced liver injury in male rats. Turkish journal of biology, $36(2), 217-223$.

17. Mahmood, S. A., Amin, K. A. and Salih, S. F. (2015). Effect of acrylamide on liver and kidneys in albino wistar rats. International Journal of Current Microbiology and Applied Sciences, 4 (5), 434-44.

18. Bancroft, J. D. and Gamble, M. (Eds.). (2008). Theory and practice of histological techniques. Elsevier health sciences.

19. Shalaby, A. M., hamid Ibrahim, M. A. A. and Aboregela, A. M. (2019). Effect of aspartame on the placenta of adult albino rat. A Histological and Immunohistochemical Study. Annals of AnatomyAnatomischer Anzeiger, 224, 133-141.

20. Kisielinski, K., Willis, S., Prescher,A., Klosterhalfen, B. and Schumpelick, V. (2002). A simple new method to calculate small intestine absorptive surface in the rat. Clinical and experimental medicine, $2(3), 131-135$.

21. Schiller, C. M. and Walden, R. (1977). Development of substrate cycle enzymes in the hamster small intestine. Developmental biology, 60 (1), 130-138.

22. Lowry, O. H., Rosebrough, N. J., Farr, A. L. and Randall, R. J. (1951). Protein measurement with the Folin phenol reagent. Journal of biological chemistry, 193, 265-275.

23. Schiller, C. M. and Lucier, G. W. (1978). The differential response of isolated intestinal crypt and tip cells to the inductive actions of $2,3,7$, 8-tetrachlorodibenzo-p-dioxin. Chemico-biological interactions, 22 (2-3), 199-209.

24. Schiller, C. M., Taylor, W. M. and Halperin, M. L. (1974). Control of fatty acid synthesis in white adipose tissue by insulin: Coordination between the mitochondrial citrate transporter and pyruvate dehydrogenase. Canadian journal of biochemistry, 52 (10), 813-821. 
25. Wahlefeld,A. W. (1974). Triglycerides determination after enzymatic hydrolysis. In Methods of enzymatic analysis. Academic Press, 1831-1835

26. Lucier, G. W. and McDaniel, O. S. (1972). Alterations in rat liver microsomal and lysosomal $\beta$-glucuronidase by compounds which induce hepatic drug-metabolizing enzymes. Biochimica et Biophysica Acta (BBA)-General Subjects, 261 (1), 168-176.

27. Ohkawa, H., Ohishi, N. and Yagi, K. (1979). Assay for lipid peroxides in animal tissues by thiobarbituric acid reaction. Analytical biochemistry, 95 (2), 351-358.

28. Beutler, E. (1963). Improved method for the determination of blood glutathione. The journal of laboratory and clinical medicine, 61, 882-888.

29. Sun, Y. I., Oberley, L. W. and Li, Y. (1988). A simple method for clinical assay of superoxide dismutase. Clinical chemistry, 34 (3), 497-500.

30. Al-Rejaie, S. S., Aleisa, A. M., Sayed-Ahmed, M. M., AL-Shabanah, O. A., Abuohashish, H. M., Ahmed, M. M., Al-Hosaini, K.A. and Hafez, M.M. (2013). Protective effect of rutin on the antioxidant genes expression in hypercholestrolemic male Westar rat. BMC complementary and alternative medicine, 13 (1), 136.

31. Mottram, D. S., Wedzicha, B. L. and Dodson, A. T. (2002). Acrylamide is formed in the Maillard reaction. Nature, 419 (6906), 448-449.

32. Erdreich, L. S. and Friedman, M. A. (2004). Epidemiologic evidence for assessing the carcinogenicity of acrylamide. Regulatory Toxicology and Pharmacology, 39 (2), 150-157.

33. Walden, R., Squibb, R. E. and Schiller, C. M. (1981). Effects of prenatal and lactational exposure to acrylamide on the development of intestinal enzymes in the rat. Toxicology and applied pharmacology, 58 (3), 363-369.

34. Takahashi, M., Shibutani, M., Inoue, K., Fujimoto, H., Hirose, M. and Nishikawa, A. (2008). Pathological assessment of the nervous and male reproductive systems of rat offsprings exposed maternally to acrylamide during the gestation and lactation periods - a preliminary study. The Journal of toxicological sciences, 33 (1), 11-24.

35. Zödl, B., Schmid, D., Wassler, G., Gundacker, C., Leibetseder, V., Thalhammer, T. and Ekmekcioglu, C. (2007). Intestinal transport and metabolism of acrylamide. Toxicology, 232 (1-2), 99-108.

36. Altinoz, E. and Turkoz, Y. (2014). The protective role of $\mathrm{N}$-acetylcysteine against acrylamide-induced genotoxicity and oxidative stress in rats. Gene Therapy and Molecular Biology, 16, 35-43.
37. Gedik, S., Erdemli, M. E., Gul, M., Yigitcan, B., Gozukara Bag, H., Aksungur, Z. and Altinoz, E. (2018). Investigation of the protective effects of crocin on acrylamide induced small and large intestine damage in rats. Biotechnic \& Histochemistry, 93 (4), 267-276.

38. Moonen, R. M., Kessels, C. G., Zimmermann, L. J. and Villamor, E. (2012). Mesenteric artery reactivity and small intestine morphology in a chicken model of hypoxia-induced fetal growth restriction. Journal of Physiology and Pharmacology, 63, 601-612.

39. Hułas-Stasiak, M., Dobrowolski, P. and Tomaszewska, E. (2015). Maternal Acrylamide and Effects on Offsprings. Acrylamide in Food: Analysis, Content and Potential Health effects, 93.

40. Ølstørn, H. B. A., Paulsen, J. E. and Alexander, J. (2007). Effects of perinatal exposure to acrylamide and glycidamide on intestinal tumorigenesis in Min/ + mice and their wild-type litter mates. Anticancer research, 27 (6B), 3855-3864.

41. Park, J., Kamendulis, L. M., Friedman, M. A. and Klaunig, J. E. (2002). Acrylamide-induced cellular transformation. Toxicological Sciences, 65 (2), 177-183.

42. Maronpot, R. R., Thoolen, R. J. M. M. and Hansen, B. (2015). Two-year carcinogenicity study of acrylamide in Wistar Han rats with in utero exposure. Experimental and Toxicologic Pathology, 67 (2), 189-195.

43. Gey, K. F. (1993). Prospects for the prevention of free radical disease, regarding cancer and cardiovascular disease. British Medical Bulletin, 49 (3), 679-699.

44. Speit, G., Dennog, C., Radermacher, P. and Rothfuss, A. (2002). Genotoxicity of hyperbaric oxygen. Mutation Research/Reviews in Mutation Research, 512 (2-3), 111-119.

45. Turella, P., Cerella, C., Filomeni, G., Bullo, A., De Maria, F., Ghibelli, L., Ciriolo, M.R., Cianfriglia, M., Mattei, M., Federici, G. and Ricci, G. (2005). Proapoptotic activity of new glutathione S-transferase inhibitors. Cancer research, 65 (9), 3751-3761.

46. Burg, D., Riepsaame, J., Pont, C., Mulder, G. and van de Water, B. (2006). Peptide-bond modified glutathione conjugate analogs modulate GST $\pi$ function in GSH-conjugation, drug sensitivity and JNK signaling. Biochemical pharmacology, 71 (3), 268-277.

47. Suzuki, N., Svensson, K. and Eriksson, U. J. (1996). High glucose concentration inhibits migration of rat cranial neural crest cells in vitro. Diabetologia, 39 (4), 401-411.

48. Siman, C. M., and Eriksson, U. J. (1997). Vitamin C supplementation of the maternal diet reduces the rate of malformation in the offsprings of diabetic rats. Diabetologia, 40 (12), 1416-1424. 
الملخص العربى

الدور المُحسّن المحتمل لحمض الأسكوربيك في التغيرات المعوية الناجمة عن الأكريلاميد

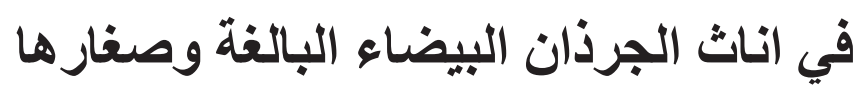

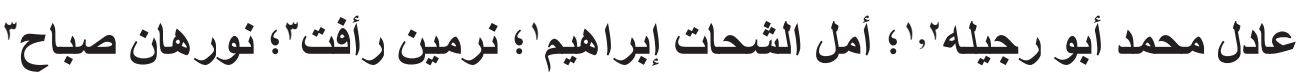

القسم التشريح والأجنة بكلية الطب البشري جامعة الزقازيق مصر

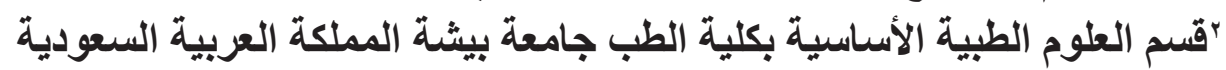

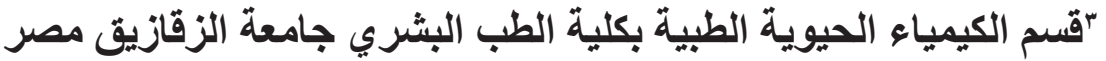

المقدمة: أكريلاميد (ACR) عبارة عن مركب طبيعي يستخدم على نطاق واسع. وجد أن تناول كميات كبيرة من أكريلاميد يكمن ور اء العديد من المخاوف الصحية و المسخية. ويعتبرحمض أسكوربيك (فيتامين C) عامل فعال من وهن مضادات الأكسدة الذى يقلل كثير ا من الأضر ار الناتجة عن الجذور الحرة. الهدف من البحث: تهدف هذه الدر اسة الى متابعة الاضطر ابات و التغيرات المورفومترية النسيجية ، و الكيمونسيجية

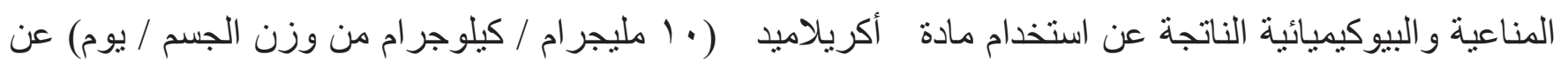
طريق إستخدام الأنبوب المعدي في أمعاء إناث الجرذان البيضاء وصغار ها. كذلك ، الدور المحسّن لحضض أسكوربيك منيك ( ( . ملغ / كغ / يوم) عن طريق إستخدام الأنبوب المعدي. المواد و الطرق: تم تقسيم • ع من اناث الجرذان البيضاء البالغة الي اربع مجموعات. المجمو عة الضابطة و مجموعة

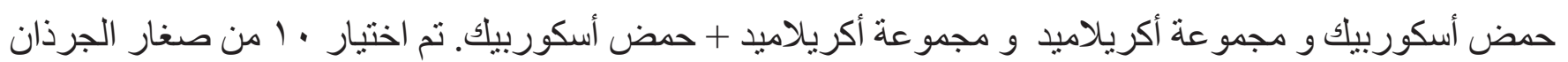
عشو ائيا من كل مجمو عة بعد الفطام و استخدمت ايضا في البحث. تم عمل تحليل هستومورفومثري لجدار الأمعاءو تم عمل تحليل كيميائي لانزيمات الامعاء و علامات الأكسدة ومضادات الأكسدة وبعض الجينات. النتائج: في كلا المجمو عتين من الأمهات وصغار ها ، وجد أن مادة الاكريلاميد قد أدت الي تضخم في الغثاء المخاطي JITV للامعاء وارتثاح التهابي داخل ظهارة الأمعاء الزغبية. بالإضافة إلى نقص في عدد خلايا جوبلت و خلايا الموجبة في الأمهات و زيادتها في الصغار.كما تسبب الاكريلاميد أيضا في نقص مستوي أنزيم سيترات سينسيزو جلوتاثيون و كاناليز في الصغار و زيادة بيتا جلوكورونيداز و مالونايلديهيد في الأمهات. أما في الصغار قل مستوي الكالاين فوسفاتاز و زاد البيتاجلوكورونيداز .كما زاد تعبير mRNA للجلو تاثيون بيروكسيداز و جلو تاثيون ريداكتاز بدرجة لها دلالة احصائية مع استخدام الاكريلاميد. و ووجد أن استخدام حمض الاسكوربيك قد حافظ على الحالة المثلي في معظم الحالات الخلاصة: إن تناول الاكريلاميد أثناء الحمل و الرضاعة له كثير من المخاطر وذللك بسبب اثتارة تضخم الغتاء المخاطي

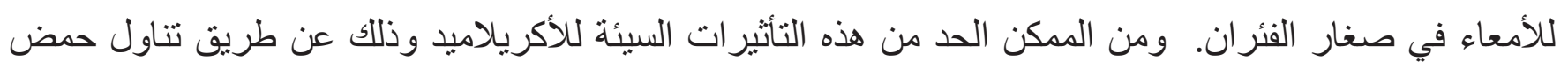
الأسكوربيك مع الاكريلاميد. 